\title{
Polskie interpretacje totalitaryzmu. O niektórych efektach prac prowadzonych w Ośrodku Badań nad Totalitaryzmami im. Witolda Pileckiego*
}

Totalitaryzm budził badawcze zainteresowania niemalże już od pierwszych chwili swego wyodrębnienia się jako nowej idei i nowego elementu pejzażu społeczno-politycznego Europy. Interesujących analiz tego zjawiska dostarczyli już teoretycy polityki i piastunowie władzy żyjący w dwudziestoleciu międzywojennym. $Z$ oczywistych powodów totalitaryzm stał się zatem przedmiotem wzmożonej refleksji zarówno w okresie panowania reżimów totalitarnych, jak i po ich demontażu. Upływ czasu, który niemalże całkowicie pozwolił obnażyć ich antyhumanitarne oblicze oraz uwypuklić elementy konstytutywne nie tylko tego typu ustrojów politycznych, lecz także i sposobów myślenia, nie spowodował też zaniechania eksploracji tematu przez współczesnych. Uzasadnień do ciągłego podejmowania dociekań w tym przedmiocie dostarcza zarówno potrzeba zachowania pamięci historycznej, jak i zdystansowanego czasowo, pogłębionego namysłu nad ideowymi oraz praktycznymi aspektami korzeni, fenomenu zarządzania i konsekwencji rządów totalitarnych. Ważnego argumentu przemawiającego za żywotnością rzeczonego obszaru dostarcza również badawcza ciekawość jego objaśniania i oceny na tle cech systemów politycznych występujących w epokach wcześniejszych oraz w aktualnych realiach. Co więcej, przypominanie i propagowanie wiedzy wśród pokoleń bezpośrednio niedotkniętych skutkami panowania dyktatur totalitarnych pozwala przestrzec przed ewentualnymi sympatiami oraz

* Doświadczenie dwóch totalitaryzmów. Interpretacje, red. P. Kaczorowski et al., Ośrodek Badań nad Totalitaryzmem im. Witolda Pileckiego, Warszawa 2018, ss. 524. 
próbami ich recepcji, a także przed relatywizowaniem ich zbrodniczych dokonań we współczesnej debacie. Równie istotne jest w tym kontekście, zwłaszcza W warunkach panowania autorytetu środków masowego przekazu o różnej proweniencji, przywracanie pewnym pojęciom i procesom z zakresu totalitaryzmu rzetelnych oraz uprawnionych historycznie (faktycznych) treści. Utrwalanie wypracowanych przez naukę i publicystykę właściwych im znaczeń może przysłużyć się do eliminowania w przestrzeni publicznej nadużyć i manipulacji językowych upowszechniających niepoprawne stereotypy, dokonujących nieuprawnionej stygmatyzacji pewnych poglądów i zachowań czy wreszcie kształtujących dyletancką postawę. Posługiwanie się w określonym obszarze badawczym, w tym wypadku dotyczącym teorii i praktyki totalitaryzmu, terminami o ustalonych polach semantycznych ma bowiem niezmiernie istotny walor porządkujący i systematyzujący wiedzę. Przyczynia się tym samym do przejrzystości i ubogacenia wiedzy oraz - co warte podkreślenia - do merytorycznego dyskursu w przedmiocie (re)interpretacji danego zjawiska z perspektywy różnych dyscyplin naukowych i stanowisk światopoglądowych.

Zasygnalizowane przyczyny ciągłego analizowania zjawiska totalitaryzmu prowadzą do pojawiania się na rynku wydawniczym licznych, mniej lub bardziej godnych uwagi, dysertacji naukowych (o czym będzie jeszcze mowa). Godzi się też zauważyć, że zainteresowanie tą tematyką dotyczy nie tylko stosunkowo wąskiego grona osób specjalizujących się w tym obszarze badań, lecz także widoczne jest $\mathrm{w}$ pozytywnym odzewie na ofertę edukacyjną niektórych polskich uczelni wyższych, zakładającą poszerzanie i upowszechnianie wiedzy o totalitaryzmie. Mam tu szczególnie na uwadze specjalizację wiedza o Holokauście i ludobójstwach włączoną do programu na drugim stopniu studiów magisterskich na kierunku europeistyka na Uniwersytecie Jagiellońskim czy też studia podyplomowe o nazwie Totalitaryzm-Nazizm-Holokaust prowadzone przez Państwowe Muzeum Auschwitz-Birkenau w Oświęcimiu we współpracy z Uniwersytetem Pedagogicznym w Krakowie. Programy wspomnianych kursów dydaktycznych, korespondując $\mathrm{z}$ aktywnością badawczą ośrodków naukowych działających w kraju i za granicą, wychodzą najwyraźniej naprzeciw oczekiwaniom tej części polskiego społeczeństwa, które chce zajmować się tą trudną, wielowątkową i nadal w pełni niepoznaną tematyką, zwłaszcza w przedmiocie praktyk reżimów totalitarnych w Europie Środkowo-Wschodniej.

Przytoczone pobudki miały zapewne decydujące znaczenie również w powołaniu 29 kwietnia 2016 roku, z inicjatywy Ministerstwa Kultury i Dziedzictwa, Narodowego Ośrodka Badań nad Totalitaryzmami im. Witolda Pileckiego. Założenia statutowe ośrodka (w związku z połączeniem go od lipca 2018 roku z Instytutem Solidarności i Męstwa) niewątpliwie wpisują się w szczytną działalność badań oraz projektów edukacyjnych służących uzupełnianiu i archiwizacji wiedzy o totalitaryzmie, a szczególnie związanej z doświadczeniem panowania nazistowskiego i sowieckiego w krajach Europy Środkowo-Wschodniej. 
W trakcie ponad dwuletniej działalności instytutu podjęto w nim wiele ambitnych zadań, które pozwoliły w Polsce i na arenie międzynarodowej rozpropagować często nieznane lub zapomniane karty historii XX wieku, głównie odnoszące się do tragicznych wydarzeń mających miejsce na terytorium naszego kraju. W tym kontekście warto tylko marginalnie wspomnieć, nie umniejszając rangi innych ciekawych przedsięwzięć naukowych, o wydawanej przez Ośrodek im. W. Pileckiego serii „Zapisy Terroru”, która porządkuje i udostępnia bezcenne źródła dokumentujące tragiczne przeżycia pojedynczych i grupowych ofiar wojennych obu ustrojów. Oprócz rzeczonej publikacji na uwagę zasługuje równie wieloautorska praca zatytułowana Doświadczenie dwóch totalitaryzmów. Interpretacje. Stanowi ona efekt prac badawczych prowadzonych w latach 2017-2018 w ramach grantu o tym samym tytule. Autorom esejów zamieszczonych w publikacji zależało zwłaszcza - jak zadeklarowano we wstępie ${ }^{2}$ - na zaakcentowaniu znaczenia polskich materiałów źródłowych (indywidualnych i zbiorowych) oraz wskazaniu ich wpływu na polską tradycję naukową, intelektualną i literacką. Wydawcy podkreślili równocześnie, że oryginalność publikacji wynika z badań podjętych z perspektywy różnych dyscyplin naukowych nad niejednorodnymi przedmiotowo dokumentami (między innymi osobistymi wspomnieniami-świadectwami, piśmiennictwem fachowym, literaturą piękną, badaniami sondażowymi). To zróżnicowane treściowo ujęcie problematyki miało za zadanie pokazać specyfikę, a jednocześnie uniwersalność historii Polski z okresu dominacji nazistowskiego i sowieckiego reżimu. W tym celu podjęli się interpretacji kluczowych elementów właśnie polskiego doświadczenia totalitaryzmu przez pryzmat metodologii stosowanej w historii, historii idei, politologii, filozofii polityki, literaturoznawstwie, socjologii oraz w naukach prawnych. Zamysł ten miał dodatkowo służyć pokazaniu polskiego punktu widzenia oraz wniesieniu twórczego wkładu do światowej debaty publicznej w tym zakresie. Sytuacja, w jakiej znalazła się Rzeczpospolita Polska w okresie II wojny światowej oraz po jej zakończeniu, była bowiem - zdaniem wydawców i redaktorów tej publikacji — wyjątkowa i jednocześnie odmienna w stosunku do uwarunkowań państw Europy Zachodniej. Zasługuje ona zatem na wyeksponowanie oraz uzmysłowienie w narracji międzynarodowej jej osobliwości. Istotne fakty z dziejów naszego państwa dotyczące między innymi bezprawnego naruszenia granic we wrześniu 1939 roku przez Trzecią Rzeszę i Związek Radziecki, zaplanowanej skutecznej eliminacji polskiej inteligencji (cywilnej i wojskowej) przez obu okupantów czy też narzucenie od 1944 roku przez Józefa Stalina rządów komunistów na wyzwolonych

${ }^{1} \mathrm{~W}$ ramach serii ukazały się następujące tomy: Zapisy terroru. Warszawa, t. 1, „Zapisy Terroru” t. 1, Warszawa 2017, ss. 260; Zapisy terroru. Warszawa, t. 2, „Zapisy Terroru”, t. 2, Warszawa 2018, ss. 272; Zapisy terroru. Okupacja niemiecka $w$ dystrykcie radomskim, „Zapisy Terroru”, t. 3, Warszawa 2018, ss. 284; Zapisy terroru. Zbrodnie niemieckie w Śródmieściu podczas Powstania Warszawskiego, „Zapisy Terroru”, t. 4, Warszawa 2018, ss. 264.

${ }^{2}$ W. Kozłowski, T. Stefanek, Od wydawcy, [w:] Doświadczenie..., s. 9-11. 
ziemiach polskich (zgodnie z postanowieniami podjętymi w Jałcie i Poczdamie przez Wielką Trójkę) w historiografii światowej często stanowią tematy niewygodne, niezauważalne, świadomie pomijane czy nawet słabo znane. Tym bardziej nie tylko z perspektywy polskiej, lecz także zewnętrznych obserwatorów wydaje się konieczne odkrywanie, poznawanie i rozliczanie z dramatycznymi obliczami historii XX wieku, której meandry boleśnie dotknęły Polskę.

Zanim przejdziemy do syntetycznego omówienia rzeczonej publikacji, warto zwrócić uwagę na jej tytuł, który być może w niezamierzony przez jej redaktorów sposób sugeruje, że dotyczy interpretacji dwóch totalitaryzmów. Co znamienne, sami autorzy wielokrotnie podkreślają w swoich esejach (i ich tytułach), zgodnie zresztą z utrwaloną tezą badawczą, że na poziomie definicyjnym możemy mówić o teorii (a nie teoriach) totalitaryzmu ${ }^{3}$, w jej zaś obrębie wyróżniamy odmienne warianty - formy i postaci (przejawiające się między innymi w rodowodzie ruchu, ideologii, programach, rozwiązaniach ustrojowych) wykazujące się jednocześnie wspólnymi konstytutywnymi cechami zarówno w ujęciu funkcjonalnym, jak i antropologicznym ${ }^{4}$. Można przypuszczać, że zastosowany uzus językowy (zawarty też w nazwie samego Ośrodka) ma charakter skrótu myślowego mającego na celu wyeksponowanie swoistości przypadku państwa polskiego poddanego, wbrew jego racji stanu i woli większości obywateli, dwóm reżimom totalitarnym. $\mathrm{W}$ przeciwnym razie redaktorzy powinni rozpocząć publikację od tekstu teoretycznego, w którym podaliby argumenty wskazujące na możliwość rozbicia idei totalitaryzmu na dwa odrębne byty oraz sformułowaliby definicje obu totalitaryzmów $^{5}$.

${ }^{3}$ Por. rozważania P. Kaczorowskiego, Nieludzkie, antyludzkie. Rzeczywistość totalitaryzmu i jej poznawanie. Próba namystu, [w:] Doświadczenie..., s. 41 n.; oraz P. Madajczyka, Totalitaryzm w badaniach polskich i niemieckich, [w:] Doświadczenie..., s. 116, 120 n. Inaczej w studium Jana Olaszka, przy którego lekturze odnosi się wrażenie, że autor świadomie pisze o dwóch totalitaryzmach - nazistowskim i komunistycznym, jednocześnie nie odnosząc się ani do definicji totalitaryzmu, ani nie sygnalizując różnic między tymi dwoma teoriami; zob. idem, Dwa totalitaryzmy w publikacjach drugiego obiegu w PRL-u, [w:] Doświadczenie..., s. 384. Podobnie A. Wysocki, Pamięć zbiorowa o okupacji hitlerowskiej, sowieckiej i o PRL-u jako element wspótczesnej tożsamości narodowej Polaków w perspektywie badań sondażowych, [w:] Doświadczenie..., s. 454, 456.

4 Por. definicyjne ujęcie terminu: H. Arendt, Korzenie totalitaryzmu, t. 1-2, Warszawa 1993; M. Bankowicz, Totalitaryzm, [hasło w:] Słownik społeczny, red. B. Szlachta, Kraków 2004, s. 1481, 1489; A. Rzegocki, Totalitaryzm, [hasło w:] Stownik historii doktryn politycznych z suplementem, t. 6, red. K. Chojnicka, M. Jaskólski, Warszawa 2015, s. 153; H. Olszewski, M. Zmierczak, Historia doktryn politycznych i prawnych, Poznań 1993, s. 365; Doktryny polityczne XIX i XX wieku, red. K. Chojnicka, W. Kozub-Ciembroniewicz, Kraków 2000, s. 333.

5 O poziomie terminologicznego zagubienia cechującego omawianą publikację może świadczyć artykuł wprowadzający autorstwa współredaktorki książki Joanny Lubeckiej zatytułowany Polska wobec dwóch totalitaryzmów - doświadczenie niechciane. Wprowadzenie (w Doświadczenie..., s. 13-36). Z jednej strony zarówno w tytule, jak i w tekście autorka wielokrotnie wspomina o „dwóch totalitaryzmach”, a z drugiej deklaruje, że istniał ,jeden totalitaryzm i wiele doświadczeń”. Takie podejście nie sprzyja precyzji, która winna charakteryzować pracę naukową. 
Poza kwestią dotyczącą brzmienia tytułu pewne wątpliwości nasuwają się również w związku z wewnętrzną strukturą pracy. Zgodnie ze spisem treści została ona podzielona na trzy zasadnicze części, którym nadano następujące nazwy: Anatomia totalitaryzmu; Doświadczenie zbrodni: zamyst, świadectwo, rozliczenie; Doświadczenie zniewolenia: opór, refleksja, pamięć. Zastosowana klasyfikacja wydaje się prawidłowa, ponieważ rzeczowo porządkuje rozdziały od rozważań teoretycznych o totalitaryzmie (część I), przez polską intelektualną i empiryczną perspektywę przeżyć wojennych (część II), do wybranych studiów przypadków bezpośrednio związanych z panowaniem systemu nazistowskiego i komunistycznego (część III). Natomiast poruszana w nich problematyka, głównie w części II i III, jest dość rozległa i wielowątkowa, co powoduje, że trudno znaleźć motyw przewodni uzasadniający dobór na ogół nieprzystających do siebie opracowań badawczych zgromadzonych w omawianym tomie. Oczywiście koncepcja prac wieloautorskich zezwala na swobodę w zestawianiu materiału merytorycznie zróżnicowanego, dla którego wiążący pozostaje tytuł główny lub podtytuły pracy. W tym wypadku jednak mimo takiego założenia pojawia się niezaspokojona ciekawość co do użytego systemu wyboru tekstów do rzeczonej publikacji.

Przykładowo nie do końca zrozumiałe jest zamieszczenie w części III artykułu poświęconego analizie oraz ocenie znaków semantycznych charakterystycznych dla litewskiej i słowackiej narracji historiograficznej dotyczącej zachowań wobec władz komunistycznych tych krajów po 1956 roku. Tekst ten stanowi bowiem wyjątek wśród pozostałych, skupionych na totalitaryzmie w kontekście osobliwego polskiego doświadczenia, artykułów. Przypomnę, że właśnie owo specyficznie polskie doświadczenie miało być przedmiotem całego zbioru, wprowadzenie więc odmiennej tematyki burzy konstrukcję pracy. Omawiany tu tekst autorstwa Katarzyny Korzeniewskiej ${ }^{6}$ zyskałby zresztą na wartości merytorycznej, gdyby jego przedmiot został umieszczony na tle polskiego doświadczenia (co autorka czyni pobieżnie i oszczędnie, w zasadzie tylko krótko relacjonując typologię wypracowaną głównie przez polskich naukowców i częściowo wykorzystywaną przez słowackich pisarzy). Sam temat jest o tyle atrakcyjny poznawczo, o ile pozwala na poziomie słownictwa - co we wstępie sygnalizuje autorka uchwycić i skomentować postawy niezgody wobec panującego systemu rządów. Poznanie rodzimej specyfiki kategorii językowych, zwłaszcza na tle dorobku innych krajów, które po II wojnie światowej znalazły się w podobnym położeniu, bez wątpienia wzbogaciłoby wiedzę w obszarze słabo rozpoznawalnym przez środowiska naukowe Zachodu, a istotnym dla dojrzałego i szerokiego ujęcia doświadczenia różnych form zniewolenia przez totalitaryzm. Na marginesie można tu jeszcze wskazać na występujący w tekście brak szerszego odniesienia się do

${ }^{6}$ K. Korzeniewska, Dlaczego na Litwie i Stowacji nie było „,opozycji”? O pojęciach określajacych sprzeciw wobec władzy po 1956 roku, [w:] Doświadczenie..., s. 415-452. 
bogatego dorobku lingwistyki (chociażby kanonicznej pracy Victora Klemperera o Lingua Tertii Imperii) dotyczącego specyfiki języka w systemach totalitarnych.

Powracając do układu treściowego pracy, godzi się zwrócić uwagę na kluczową ze względów terminologicznych część zatytułowaną Anatomia totalitaryzmu (składającą się z trzech oddzielnych tekstów autorstwa Pawła Kaczorowskiego, Marka Kornata i Piotra Madajczyka). W tej części publikacji solidnie zaprezentowano dotychczasowe najistotniejsze ustalenia badawcze i interpretacje $\mathrm{w}$ odniesieniu do teorii totalitaryzmu oraz jego europejskich postaci, wypracowane w światowym i krajowym dorobku intelektualnym. Choć niewątpliwie warto byłoby przy okazji rozważań o prekursorach w przedmiocie badań nad totalitaryzmem wspomnieć o włoskim socjaliście Leliu Basso, kapłanie i prekursorze włoskiej chadecji Luigim Sturzo czy też francuskojęzycznym publicyście o proweniencji socjalistycznej, działaczu Kominternu Victorze Serge (wł. Wiktor Kibalczicz). Ich publikacje w pewnym stopniu przyczyniły się do upowszechnienia pojęcia totalitaryzmu u początków powstawania tego systemu, nadając mu pejoratywne znaczenie zarówno w stosunku do rodzącego się faszyzmu, jak i stalinowskiej Rosji ${ }^{7}$.

Ze wspomnianymi dociekaniami na temat uwikłania totalitaryzmu rzeczowo koresponduje tekst autorstwa Arkadiusza Górnisiewicza ${ }^{8}$. Otwiera on kolejną część tomu, chociaż względy merytoryczne wskazywałyby raczej na potrzebę jego umiejscowienia w Anatomii totalitaryzmu, a nie w części II eksponującej wybrane intelektualne i empiryczne płaszczyzny totalitaryzmu okresu wojny. Górnisiewicz analizuje tu bowiem godne upamiętnienia stanowiska rodzimych, wybitnych, głównie przedwojennych, myślicieli o różnych aspektach totalizmu i wiążących się z nim przyszłych zagrożeniach. Tym samym autor dowodzi wagi polskich badań nad totalitaryzmem prowadzonych jeszcze w okresie przed doświadczeniem zbrodni (w zasadzie wyjątek stanowi analiza zapisów wojennych Czesława Miłosza).

Należy się też pochylić nad nazwą nadaną części pierwszej, która przywołuje skojarzenie z tytułem publikacji autorstwa politologa i historyka Roberta O. Paxtona Anatomia faszyzmu ${ }^{9}$. Amerykański profesor (którego praca nie została niestety wykorzystana w omawianym zbiorze) podjął się w niej próby nowego ujęcia faszyzmu. Wyrazem odmienności podejścia miało tu być posłużenie się właśnie słowem ,anatomia”, za pomocą którego chciał oddać nowy sposób podejścia badawczego: poprzez wertykalne i horyzontalne przeanalizowanie pięciu stadiów ${ }^{10}$ przeistaczania się ruchów faszystowskich w reżimy (kwestionując tym samym

7 M. Bankowicz, op. cit., s. 1483-1485.

8 A. Górnisiewicz, Demokracja a totalizm: w stronę niejednoznaczności. Refleksja wybranych polskich myślicieli przed 1945 rokiem, [w:] Doświadczenie..., s. 159-186.

9 R.O. Paxton, Anatomia faszyzmu, Poznań 2005.

10 Są to następujące etapy: stworzenie ruchu, zapuszczenie korzeni w systemie politycznym, uchwycenie władzy, sprawowanie władzy i okres radykalizacji lub entropii rządów faszystowskich. 
perspektywę dychotomii ruch-reżim). Jak przekonywał, przedstawiona metoda badawcza pozwala na wiarygodne porównanie poszczególnych ruchów i rządów na właściwych im etapach rozwoju. Dowodził też, że faszyzm nie był statycznym zjawiskiem, lecz wynikiem konkretnych (umiejscowionych w miejscu i czasie) procesów i wyborów, dlatego też siatka pojęciowa pozwalająca zrozumieć jeden $\mathrm{z}$ aspektów faszyzmu niekoniecznie będzie przystawać do poznawania innych jego elementów ${ }^{11}$. Paxton zamierzał poprzez poznanie anatomii faszyzmu (skupił się głównie na włoskim i niemieckim doświadczeniu) uchwycić jego części składowe w ograniczonym im historycznie czasie i przestrzeni. Ta interesująca, lecz jednocześnie dyskusyjna (choćby ze względu na aprioryczne i dogmatyczne przyjęcie rudymentarnej jedności narodowego socjalizmu i faszyzmu) propozycja zasługiwała na odnotowanie w wydanej przez Ośrodek im. Pileckiego publikacji, zwłaszcza gdy się do niej bezpośrednio nawiązuje, nadając rozdziałowi tytuł Anatomia totalitaryzmu. Możliwe jest też jednak, że redaktorzy pracy nieświadomie odwołali się do Paxtonowskiego postulatu, o czym może świadczyć brak nawiązania do proponowanej zmodyfikowanej metody badawczej.

Wśród licznych budzących wątpliwości elementów znajdujących się w omawianej pracy trzeba odnotować niepokojącą słabą znajomość bogatego krajowego dorobku w zakresie badań nad doktrynami i systemami totalitarnymi. Tym bardziej jest to trudne do zrozumienia, gdy weźmie się pod uwagę jeden z deklarowanych celów publikacji, czyli upowszechnianie i umiędzynarodowianie krajowych badań nad totalitaryzmem. Można było zatem pokusić się o przedstawienie w osobnym — lub w ramach powstałych — tekście w szerszym niż w obecnym kształcie ustaleń wybitnych współczesnych polskich badaczy, jak Marek Bankowicz, Roman Bäcker, Jerzy Borejsza, Adam Bosiacki, Karol Jonca, Wiesław Kozub-Ciembroniewicz, Marek Maciejewski, Henryk Olszewski, Franciszek Ryszka czy Maria Zmierczak. Nawet jeżeli część prac niektórych z wymienionych autorów skupiała się głównie na faszyzmie i nazizmie (co zrozumiałe, jeżeli weźmie się pod uwagę uwarunkowania czasów PRL-u), to i tak należało zaznaczyć intelektualny wkład rodzimych uczonych w tym zakresie, który za granicą z uwagi na ,żelazną kurtynę" i barierę językową w niewielkim stopniu został dostrzeżony i wykorzystany. Pominięto też informacje o niezmiernie twórczym i długoletnim zaangażowaniu naukowym charakteryzującym wrocławski prawniczy ośrodek akademicki.

W przywołanym w pracy piśmiennictwie wypadałoby również nadmienić profil badawczy Katedry Doktryn Politycznych i Prawnych Wydziału Prawa, Administracji i Ekonomii Uniwersytetu Wrocławskiego (obecnie kierowanej przez prof. dr. hab. Marka Maciejewskiego), której pracownicy od początku jej istnienia (wcześniej w ramach Zakładu) podejmowali wraz z Franciszkiem Ryszką rozważania dotyczące Trzeciej Rzeszy. Temu celowi przyświecało zainicjowanie

11 Ibidem, s. 26-27, 265-283. 
w 1974 roku — z inicjatywy wybitnego znawcy totalitaryzmu, zwłaszcza w jego niemieckiej postaci, prof. Karola Joncy — opracowywania specjalistycznego periodyku zatytułowanego „Studia nad Faszyzmem i Zbrodniami Hitlerowskimi” (obecnie „Studia nad Autorytaryzmem i Totalitaryzmem”). Na łamach tego pisma, wyjątkowego w skali Polski i Europy, wyniki dociekań prezentowali tacy wytrawni historycy, politolodzy, prawnicy, literaturoznawcy, jak choćby: Eberhard Jäckel, Hans-Adolf Jacobsen, Ernst Nolte czy zasłużeni polscy badacze: F. Ryszka, Anna Wolff-Powęska, Franciszek Połomski, Alfred Konieczny, Henryk Olszewski, Maria Zmierczak, Czesław Madajczyk, Hubert Orłowski, Wiesław Kozub-Ciembroniewski, Marek Maciejewski, Adam Basak, Krzysztof Kawalec, Adam Bosiacki i wielu innych ${ }^{12}$. Zamieszczone w „Studiach...” do końca lat osiemdziesiątych artykuły zawierały dociekania głównie dotyczące aspektów teoretycznych, ustrojowych oraz doświadczeń włoskiego faszyzmu i nazizmu. W kolejnych latach spektrum tematyczne publikowanych tekstów rozszerzyło się o analizy między innymi iberyjskich autorytaryzmów, okresu sanacji, totalitaryzmu, bolszewizmu, PRL-u czy wreszcie współczesnych zagrożeń szeroko rozumianego terroryzmu ${ }^{13}$.

Wprawdzie można w artykułach z książki Doświadczenie dwóch totalitaryzmów... odnaleźć nieliczne odwołania do wrocławskiego periodyku, ale mimo wszystko zabrakło uzasadnionego podkreślenia blisko czterdziestopięcioletnich efektów badawczych profesora Joncy i jego uczniów, wśród których nie sposób nie zauważyć dorobku wspomnianego Marka Maciejewskiego czy też Macieja Marszała, Mirosława Sadowskiego oraz Tomasza Schefflera, a także współpracowników zatrudnionych w Instytucie Historii Państwa i Prawa tego samego wydziału: Franciszka Połomskiego, Alfreda Koniecznego, Tomasza Kruszewskiego, Leonarda Górnickiego i Józefa Koredczuka. Wspomniani wrocławscy prawnicy są też autorami istotnych przedmiotowo dysertacji analizujących różne aspekty totalitaryzmu włoskiego i nazistowskiego, ze szczególnym uwzględnieniem polskich przedwojennych interpretacji reżimów nazywanych totalitarnymi ${ }^{14}$. Ich

12 Pełny indeks autorów publikujących w latach 1974-2002 na łamach „Studiów...” można znaleźć w załączniku do tomu 25 tego periodyku, zamieszczonego w końcowej części tomu: „Studia nad Faszyzmem i Zbrodniami Hitlerowskimi” 25, 2002, s. 1-20.

13 Do 2018 roku w wersji drukowanej ukazało się 40 tomów periodyku (od 2012 roku wydawany jest jako kwartalnik).

14 Na uwagę zasługują prace o oryginalnym walorze poznawczym autorstwa Karola Joncy, których warsztat naukowy wskazuje na umiejętność łączenia analizy źródeł z ich interpretacją: m.in. opracowany z A. Koniecznym, Upadek ,Festung Breslau”, Wrocław 1963; K. Jonca, Polityka narodowościowa Trzeciej Rzeszy na Śląsku Opolskim 1933-40. Studium polityczno-prawne, Katowice 1970; K. Jonca, A. Konieczny, Nuit et Brouillard. L'operations terroriste nazie 1941-1944, Claviers 1981; Noc krysztatowa i casus Herschela Grynszpana, Wrocław 1992; Wysiedlenia Niemców i osadnictwo ludności polskiej na obszarze Krzyżowa-Świdnica (Kreisau-Schweidnitz) w latach 1945-1948 / Die Aussiedlung der Deutschen und die Ansiedlung der polnischen Bevölkerung im Raum Krzyżowa-Świdnica (Kreisau-Schweidnitz) 1945-1948. Dokumentenauswahl mit Einleitung, red. K. Jonca, M. Maciejewski, współpr. M. Marszał et al., Wrocław 1997; Dekrety prezydenta 
badawcze ustalenia zyskały poczesne miejsce w nauce, a niektóre ze wspomnianych publikacji doczekały się kilku wznowień.

Niezrozumiałe jest ponadto pominięcie w recenzowanej książce, wydanej pod patronatem Ośrodka im. W. Pileckiego, dwóch ważnych współczesnych publikacji dotyczących totalitaryzmu. Pierwsza z nich to rozpowszechniony przez krakowski Ośrodek Myśli Politycznej (znany z licznych publikacji, również źródłowych, z filozofii politycznej, w tym totalitaryzmu) i Księgarnię Akademicką,

Edvarda Beneša. Niemcy w czechostowackiej doktrynie politycznej i prawnej z lat 1920-1945, Wrocław 2005. Z kolei dorobek Marka Maciejewskiego zasadniczo oscyluje wokół nazizmu, czego efektem stały się następujące uznane osiągnięcia badawcze: Ruch i ideologia narodowych socjalistów w Republice Weimarskiej. O źródłach i początkach nazizmu 1919-1924, Warszawa-Wrocław 1985; idem, Doktryna rewolucyjnego konserwatyzmu wobec narodowego socjalizmu 1921-1945, Wrocław 1991; idem, Od piwiarnianego klubu do organizacji wywrotowej. Nazizm 1921-1924, Toruń 2005. Publikacje Macieja Marszała skupiają się na interpretacjach faszyzmu i nazizmu z perspektywy rodzimej przedwojennej myśli politycznej oraz prawnej; zob. idem, Włoski faszyzm i niemiecki narodowy socjalizm w poglądach ideologów narodowej demokracji 1926-1939, Wrocław 2001; idem, Włoski faszyzm w polskiej myśli politycznej i prawnej 1922-1939, Wrocław 2007. Badania Tomasza Schefflera zaś dotyczą totalitaryzmu (zob. np. opracowane wspólnie z Łukaszem Machajem, $Z$ badań nad procesem totalitaryzacji w nazistowskich Niemczech, „Studia nad Faszyzmem i Zbrodniami Hitlerowskimi" 27, 2004, s. 167-187), opozycji antyhitlerowskiej (T. Scheffler, Europa po Hitlerze. Ład międzynarodowy w koncepcjach konserwatywnej opozycji w Trzeciej Rzeszy, Wrocław 2006), a także ustroju PRL-u, teorii totalitaryzmu w polskim porządku prawnym (np. idem, Prawne aspekty wprowadzenia stanu wojennego $w$ Polsce $w$ dniu 13 grudnia 1981 r., [w:] Idee jako źródło instytucji politycznych i prawnych, red. L. Dubel, Lublin 2003, s. 383-403; idem, Przestepstwo publicznego propagowania faszystowskiego lub innego totalitarnego ustroju państwa (art. 256 k.k.). Analiza doktrynologiczna wybranych wypowiedzi piśmiennictwa i judykatury. Część ogólna, „Studia nad Autorytaryzmem i Totalitaryzmem” 34, 2012, nr 3, s. 97-117). Ponadto od kilku lat, wraz z M. Maciejewskim, pełni funkcję redaktora „Studiów nad Autorytaryzmem i Totalitaryzmem”. Godzi się też wspomnieć o jednym z numerów „Studiów nad Faszyzmem...”, który z inicjatywy pracowników wrocławskiej katedry został w całości poświęcony polskim interpretacjom totalitaryzmu i autorytaryzmu (32 artykuły), które stanowią niekwestionowany udział rodzimej elity intelektualnej (również migracyjnej — Zbigniewa Brzezińskiego, Richarda Pipesa) w dyskursie nad tymi systemami; szerzej zob. Polskie interpretacje totalitaryzmu i autorytaryzmu, red. M. Maciejewski, M. Marszał, „Studia nad Faszyzmem i Zbrodniami Hitlerowskimi” 33, Wrocław 2011. W recenzowanym zbiorze wspomniany tom jest cytowany raz, a w dodatku przypis został sporządzony z naruszeniem zasad pisowni pełnego opisu bibliograficznego (por. Doświadczenie..., s. 186). Rzetelnej wiedzy w tematyce, jak już wspomniano, dostarczyli również badacze z długoletnim stażem badawczym: prof. Franciszek Połomski, którego autorstwa warto przytoczyć następujące prace: idem, Niemiecki urząd do spraw mniejszości, Wrocław 1965; idem, Ustawodawstwo rasistowskie III Rzeszy i jego stosowanie na Górnym Ślasku, Wrocław 1970; idem, Aspekty rasowe w postępowanie z robotnikami przymusowymi i jeńcami wojennymi w III Rzeszy (1939-1945), Wrocław 1976; idem, Prawo własności a tzw. rozwiazanie kwestii żydowskiej w Niemczech hitlerowskich, Wrocław 1991; natomiast prof. Alfred Konieczny jest autorem m.in.: idem, Pod rzadami wojennego prawa karnego Trzeciej Rzeszy, Górny Ślask 1939-1945, Katowice 1972; idem, Akcja „Noc i mgła” w okupowanych przez III Rzesze krajach zachodniej Europy. Geneza, założenia, realizacja, Wrocław 1995; idem, Tormersdorf-Grüssau-Riebing. Obozy przejściowe dla Żydów Dolnego Ślaska z lat 1941-1943, Wrocław 1997; prof. Tomasz Kruszewski zaś jest autorem dysertacji Partia narodowosocjalistyczna na Ślasku w latach 1933-1945. Organizacja i działalność, Wrocław 1995.

Studia nad Autorytaryzmem i Totalitaryzmem 40, nr 4, 2018

(C) for this edition by CNS 
zredagowany przez Miłowita Kunińskiego zbiór artykułów o intelektualnych korzeniach trzech systemów totalitarnych oraz o ich powiązaniach z istotnymi europejskimi kierunkami filozofii i myśli politycznej ${ }^{15}$. Odnaleźć w nim można między innymi studia tak uznanych badaczy, jak Andrzej Nowak, Zdzisław Krasnodębski, Ryszard Legutko, Arkady Rzegocki czy też Roger Scruton lub Kenneth Minogue.

Druga to pochodząca z 2010 roku publikacja pod tytułem Totalitaryzmy $X X$ wieku. Idee, instytucje, interpretacje ${ }^{16}$, która wprawdzie jest raz cytowana $\mathrm{w}$ recenzowanym zbiorze, to jednak zawarty $\mathrm{w}$ niej dorobek zasługuje na zdecydowanie większą uwagę. Zgromadzony w niej materiał badawczy stanowi bowiem nie tylko interpretację (polskich, rosyjskich i niemieckich naukowców) wybranych elementów teorii totalitaryzmu, lecz także prezentuje komparatystyczne ujęcie wszystkich trzech jego europejskich postaci. W pracy znajdują się artykuły wspomnianych wytrawnych znawców tematyki, między innymi Henryka Olszewskiego, Marii Zmierczak, Marka Maciejewskiego, ale też Marka Bankowicza, Andrzeja Walickiego, Marka Kornata, Wiesława Kozuba-Ciembroniewicza czy Ewy Bojenko-Izdebskiej.

Oprócz kwestii dotyczących formalnej budowy pracy oraz doboru piśmiennictwa należy pochylić się również nad zawartością merytoryczną artykułów. Część I wykazuje się wysokim walorem poznawczym, niebudzącym poważnych kontrowersji. W zasadzie stanowi usystematyzowany przegląd głównych przeszłych i bieżących ustaleń w przedmiocie definicji oraz desygnatów totalitaryzmu. Jak się wydaje, za szczególną wartość Anatomii totalitaryzmu należy przyjąć skoncentrowanie uwagi nie tylko na ideowo-instytucjonalnym wymiarze tych systemów (łącznie z całkowicie uprawnionym namysłem nad ich zdolnością do urzeczywistnienia ${ }^{17}$ ), lecz także na perspektywie kondycji ludzkiej: człowieka uwikłanego (najczęściej wbrew woli) w antyludzkie działania machiny reżimów totalitarnych. Szczególnie ten drugi element stanowi ważką przesłankę do skonstruowania kolejnych dwóch części omawianej publikacji.

Na partię zatytułowaną Doświadczenie zbrodni: zamyst, świadectwo, rozliczenie (część II) składają się cztery teksty, a wśród nich wspomniany już artykuł

15 Totalitaryzm a zachodnia tradycja, red. M. Kuniński, Kraków 2006.

16 Totalitaryzmy XX wieku. Idee, instytucje, interpretacje, red. W. Kozub-Ciembroniewicz et al., Kraków 2010. Także w tytule tej pracy użyto w liczbie mnogiej — „totalitaryzmy”. Niemniej jednak niektórzy autorzy tekstów zbioru, na przykład Czesław Porębski (Bolszewizm, narodowy socjalizm i nihilizm, s. 41-45) i Marek Bankowicz (Autorytaryzm i totalitaryzm - analiza porównawcza, s. 25-39), zakładają rozróżnienie między doktryną totalitaryzmu a jej historycznymi odmianami ideowymi i realizacjami w ramach poszczególnych reżimów totalitarnych. W tym drugim znaczeniu może pojawiać się liczba mnoga (tak na przykład uczynił M. Bankowicz, gdy pisząc o naukowym zaklasyfikowaniu do totalitaryzmu również radzieckiego komunizmu, posłużył się sformułowaniem ,dwa totalitaryzmy” - s. 35).

17 Szerzej zob. M. Kornat, Czy istnieje totalitaryzm spetniony? W obronie kwestionowanej teorii, [w:] Doświadczenie..., s. 100-113. 
autorstwa A. Górnisiewicza oraz publikacja Tomasza Cerana zatytułowana $Z a$ głada wartościowania. Polska refleksja nad nazizmem, które sprowadzają się do zrelacjonowania dorobku polskiej intelektualnej refleksji nad totalitaryzmem. Pewien niedosyt budzi brak w recenzowanej książce tekstu, który na podobieństwo artykułu T. Cerana eksponowałby polskie doświadczenie zbrodni komunistycznych oraz nierzadko nowatorskie polskie interpretacje z zakresu sowietologii. Chodzi tu nie tyle o badania prowadzone na emigracji w Europie Zachodniej i USA, ile w Polsce, zwłaszcza po upadku komunizmu (między innymi przez Adama Bosiackiego, Marka Bankowicza, Marka Kornata, Adama Lityńskiego, Andrzeja Nowaka). Tym bardziej że polskie analizy i ustalenia w tym przedmiocie są niestety słabo rozpowszechnione.

Pozostałe dwa artykuły zamieszczone w części II dotyczą raczej empirycznych aspektów zbrodni dokonanych na Polakach i innych mieszkańcach ziem polskich. Jeden $\mathrm{z}$ nich, autorstwa Ewy Borkowskiej ${ }^{18}$, stanowi studium nad semiotycznym ujęciem kluczowych dla ofiar wojny powszechnych zagadnień, to jest kondycji dziecka, rodziny, narodu. Do założonych interesujących rozważań wprowadzają nas chyba zbytecznie powielane ustalenia definicyjne w przedmiocie totalitaryzmu (w tym jego nazistowskiej i komunistycznej wersji), dodatkowo zasadniczo ograniczone uznaniowo przez autorkę do refleksji tezami Krzysztofa Pomiana i Stanisława Salmonowicza. Niezależnie od dokonanego doboru fachowej literatury objaśniającej naturę przywołanych systemów należy stwierdzić, że poczynione dość długie wstępne wywody nie za bardzo pozostają w koniecznym związku z dalszą, zasadniczą, częścią artykułu. Główne wątki skoncentrowane są bowiem na analizie wybranych tekstów kultury (dziecięcych dzienników czasu wojny, powojennych wspomnień, literatury pięknej okresu wojny, plakatu propagandowego z czasów PRL-u), które mają trafnie dowieść przede wszystkim tragizmu losu dzieci - ofiar i jednocześnie instrumentu tak zwanej gry semiotycznej prowadzonej przez reżimy totalitarne. Zajęcie się tym obszarem badawczym ma niewątpliwy walor poznawczy, ale przy zastosowaniu kryterium przynależności narodowej do analizowania wspomnień dzieci zamieszkujących w okresie wojny tereny polskie może budzić kontrowersje. Co prawda, w prezentowanej narracji dwójki świadków zarysowana jest negatywna polityka okupanta wobec społeczności żydowskiej i jej wpływ na stan umysłu dziecięcego, to jednak nie jest to element wskazujący konieczność rozróżniania dzieci na polskie czy żydowskie, gdyż opisane w tekście doświadczenia zbrodni były w swej istocie traumatycznymi przeżyciami wszystkich dzieci. Przy przyjętej metodzie badawczej dla prawidłowego ujęcia gier semiotycznych należałoby zatem wyjść poza schemat dzieci polskie-żydowskie i rozszerzyć go o dzieci niemieckie (które w końcu też mieszkały na ziemiach polskich). To dopiero pozwoliłoby na rozpatrzenie

18 E. Borkowska, Totalitaryzmy w uniwersum semiotycznym. Dziecko-rodzina-naród, [w:] Doświadczenie..., s. 187-234. 
różnych sposobów semiotycznego oddziaływania systemu totalitarnego na dzieci. Poza tym godzi się w kontekście tego artykułu wskazać, że o ile zauważalne jest skupienie się autorki podczas analizy relacji dziecięcych czy poezji (w zasadzie ograniczonej do utworów Krzysztofa Kamila Baczyńskiego) na aspektach dramatu dziecka lub na dysfunkcjonalności rodziny w warunkach wojennych, o tyle problem narodu na poziomie omawianych znaków semiotycznych praktycznie nie występuje.

Ostatni ze znajdujących się w części II artykułów ${ }^{19}$ został poświęcony nadal otwartym sporom i ocenom kwestii prawnej kwalifikacji (w porządku krajowym i międzynarodowym) zbrodni dokonanych na członkach polskiego narodu przez niemieckich oraz sowieckich okupantów (między innymi „akcja Inteligencja”, „akcja AB”, akcje specjalne w Krakowie i Lublinie, zbrodnia katyńska). Tekst Macieja Jana Mazurkiewicza został oparty na stosunkowo licznej literaturze polskiej i zagranicznej. Zabrakło w nim jednak odniesień do rosyjskich ustaleń naukowych. Poza tym zasłużenie opisany wątek klasyfikacji zbrodni niemieckich i sowieckich dokonany przez polskich historyków oraz prawników, zwłaszcza w kontekście sprawy katyńskiej, byłby rzeczowo cenniejszy, gdyby autor uwzględnił uzasadnienia rozbieżności w zastosowanej przez nich typologii tych przestępstw. W szczególności istotne byłoby zwrócenie uwagi na relewantne prawnie rozgraniczenie „zbrodni przeciwko ludzkości” oraz „ludobójstwa”. Wprawdzie w artykule przypomina się o Rafale Lemkinie kojarzonym z koncepcją genocydu, ale warto by było również nadmienić, że do grona osób opracowujących podstawy prawne funkcjonowania Międzynarodowego Trybunału Wojskowego w Norymberdze należał autor terminu i koncepcji ,zbrodni przeciw ludności”, urodzony na ziemiach dawnej Rzeczypospolitej (Żółkwi), polski prawnik narodowości żydowskiej Hersch Lauterpacht ${ }^{20}$.

Część III publikacji zawiera cztery artykuły, które koncentrują się na elementach związanych z wpływem totalitaryzmu na stan świadomości i postawę Polaków (aczkolwiek tekst K. Korzeniewskiej dotyczy Litwinów i Słowaków) żyjących w okresie PRL-u oraz współcześnie. Pierwsze dwa teksty odnoszą się do roli i interpretacji szczególnego rodzaju piśmiennictwa (wydawanego za granicą i w kraju), będącego świadectwem kondycji psychicznej oraz intelektualnej Polaków w okresie reżimu komunistycznego po II wojnie światowej. Pierwszy z nich $^{21}$ został poświęcony poczytnemu dziełu Czesława Miłosza Zniewolony umyst oraz zawartej $\mathrm{w}$ nim diagnozie zróżnicowanych postaw rodzimej elity

19 M.J. Mazurkiewicz, Ludobójstwo? Prawnomiędzynarodowa kwalifikacja wybranych niemieckich i sowieckich zbrodni na narodzie polskim (1939-1945) w świetle ustaleń polskiej doktryny, [w:] Doświadczenie..., s. 295-333.

20 Szerzej zob. A. Rezik, Hersch Lauterpacht (1897-1960) - droga do nauki prawa międzynarodowego, „Palestra” 2017, nr 10, s. 52-60.

21 W. Rechlewicz, Mechanizmy zniewolenia umysłów wedlug Czesława Miłosza, [w:] Doświadczenie..., s. 337-379. 
intelektualnej i artystycznej wobec narzuconego systemu. Wojciech Rechlewicz stawia tu tezę, że ponadczasowość książki Miłosza wynika z trafności zamieszczonej w niej oceny przyczyn i mechanizmów zachowań intelektualistów wchłoniętych przez system totalitarnych. Na tej kanwie Rechlewicz proponuje, aby owe zachowania rozpatrywać na dwóch płaszczyznach — naukowej i moralnej. Pierwsza, naukowa perspektywa badawcza miałaby rzekomo pozwolić na prowadzenie zobiektywizowanej, pozbawionej wartościowania analizy. Dzięki niej wyjaśnialibyśmy współpracę intelektualistów z reżimem totalitarnym jako pochodną instynktu samozachowawczego oraz częściowo także jako wyraz wrodzonego egoizmu. Takie hobbesowskie ujmowanie istoty człowieka (intelektualisty) — wbrew deklaracji autora — nie ma jednak nic wspólnego z naukowym obiektywizmem, gdyż jest wyrazem określonego ideowo zaangażowanego założenia antropologicznego, którego przyjęcie w tym konkretnym wypadku implicite dąży do swoistego „uniewinnienia” sprawców. Odnosząc się do drugiej, moralnej płaszczyzny badawczej, Rechlewicz wskazuje, że jej potencjalną wadą jest nieprzystawalność dzisiejszych ocen do warunków, które mają być oceniane. Okoliczności historyczne uwarunkowane istnieniem reżimu totalitarnego nie pozwalają w jego opinii na jednoznaczne kwalifikowanie ówczesnych zachowań ludzkich, zwłaszcza z dzisiejszej perspektywy. Tekst Rechlewicza zawiera zatem nie do końca jasno sformułowane założenie o możności, a nawet konieczności zrelatywizowania ocen odnoszących się do zachowań intelektualistów okresu panowania reżimu komunistycznego. Postawa ta dla swej pełności wymagałaby akceptacji podobnego nastawienia wobec intelektualistów ,zniewolonych” przez system nazistowski. Warto byłoby, aby autor w przyszłości zgłębił prozę i losy Tadeusza Borowskiego, gdyż zapewne pomogłoby mu to w bardziej precyzyjnym ustaleniu konsekwencji własnego stanowiska.

Kolejny artykuł w pewnym sensie koresponduje z powyższą tematyką. Traktuje w szerszym kontekście o znaczeniu, doborze i wpływie piśmiennictwa drukowanego w Polsce w tak zwanym niezależnym, drugim obiegu wydawniczym poświęconym totalitaryzmowi. Jan Olaszek w studium zatytułowanym Dwa totalitaryzmy $w$ publikacjach drugiego obiegu $w$ PRL- $u^{22}$ dowodzi sprawności realizacji pomysłu popularyzowania poza oficjalną propagandą wiedzy o totalitaryzmie. Działania te odegrały w jego opinii pozytywną rolę społeczną, gdyż przede wszystkim pozwalały na zapoznanie się z zagraniczną i polską perspektywą interpretacyjną systemów totalitarnych. Jednocześnie autor słusznie z pewnym niedosytem wskazuje, że w światowej narracji rodzime ważkie rozważania teoretyczne zostały zdominowane (a nawet niestety często niezauważone) przez informacje o empirycznych doświadczeniach zmagań z reżimem komunistycznym (zwłaszcza po 1976 roku). Co też znamienne, jak relacjonuje Jan Olaszek,

22 J. Olaszek, Dwa totalitaryzmy w publikacjach drugiego obiegu w PRL-u, [w:] Doświadczenie..., s. 381-413. 
polskie podziemne publikacje, które cechowały się znaczącym potencjałem twórczym w odniesieniu do totalitaryzmu, niestety były i także dziś są zbyt słabo znane w obiegu naukowym.

Już na wstępie artykułu mówiłam o tekście autorstwa K. Korzeniewskiej. Poza zasygnalizowanymi wówczas kwestiami warto zwrócić jeszcze uwagę na wątpliwości dotyczące użytej metody badawczej wobec słownictwa opisującego postawy osób pozostających w opozycji względem komunistycznych władz na Litwie i Słowacji. Oczywiście z punktu widzenia badań naukowych istotne jest wykazanie specyfiki językowej siatki pojęciowej charakterystycznej dla każdego $\mathrm{z}$ analizowanych przypadków i wyciągnięcie na tej podstawie komparatystycznych konkluzji. Warto przy tej okazji wskazać na pewien deficyt w refleksji nad genezą omawianych terminów. Przykładowo - jak zaznacza sama autorka ważne w litewskiej narracji określenie „okupacja” nie występuje raczej w słowackim dyskursie naukowym i publicystycznym ${ }^{23}$. Nie zastanawia się ona jednak nad przyczynami tego zjawiska, co utrudnia zrozumienie różnić w sferze semantycznej obu społeczeństw. Godzi się zatem przypomnieć, że w wypadku Litwy krytycy panującego wówczas nad Niemnem reżimu sowieckiego posługiwali się pojęciem „okupacja”, aby utrwalić w rodzimym formalnoprawnym i potocznym języku fakt utraty niepodległości. W odróżnieniu od Słowaków poczucie tradycji państwowo-narodowej w przypadku Litwinów może sięgać przecież do czasów Wielkiego Księstwa Litewskiego, a na pewno mocno zakorzenione zostało w międzywojniu, gdy istniało niepodległe państwo litewskie (1918-1940). Natomiast w wypadku społeczeństwa słowackiego poczucie okupacji miało znacznie mniej oczywiste zakotwiczenie w historii: po pierwsze, jego niezależność polityczna datowana jest dopiero na 1938 rok, a po drugie, ich państwowość powstała w wyniku współpracy z Trzecią Rzeszą. Stygmat kolaboracji z nazistowskimi Niemcami może mieć bardzo dużą moc oddziaływania, o czym może świadczyć polska pamięć historyczna (a właściwie jej brak) odnosząca się do Zaolzia. Unikanie głębszego wnikania w uwarunkowania historyczne popularności (bądź jej braku) pewnych słów, pojęć czy terminów niestety charakteryzuje cały artykuł24. Jest to o tyle zadziwiające, że - jak deklaruje sama autorka - pisząc omawiany esej (tak określa swój tekst, odwołując się do francuskiego słowa essai oznaczającego próbę), starała się podjąć próbę „bycia historykiem pojęć”. Warto w tym kontekście odnotować, że autorka składając wspomnianą deklarację, odwoływała się do propozycji metodologicznej Haydena White'a (nawiązującej z resztą do Begriffsgeschichte Reinharta Kosellecka), która nie należy do prostych w realizacji. Dla przykładu można tu wskazać, że pod jej wpływem przyjęty został podział środowisk opozycyjnych na religijne ${ }^{25}$ i świeckie na zasadzie oczywistości.

23 Zob. K. Korzeniewska, op. cit., s. 423.

24 Szczególnie znamienne jest to w odniesieniu do terminu ,totalitaryzm”; zob. ibidem, s. 421.

25 Szkoda też, że autorka, skupiając uwagę na tak zwanych środowiskach sprzeciwu o proweniencji religijnej vel kościelnej (w sposób uprawniony kojarzonych z dominującym w tych pań- 
Autorka nie zauważyła jednak, że w ten sposób jej praca badawcza naraża się na zarzut ahistoryzmu.

Ostatni z omawianych tekstów, autorstwa Artura Wysockiego, nosi tytuł $P a$ mięć zbiorowa o okupacji hitlerowskiej, sowieckiej i o PRL-u jako element wspótczesnej tożsamości narodowej Polaków w perspektywie badań sondażowych ${ }^{26}$. $\mathrm{W}$ jego wstępie autor entuzjastycznie informuje, że w społeczeństwie polskim wyraźnie wzrosło zainteresowanie historią. Świadczyć o tym, jego zdaniem, ma pozytywny oddźwięk społeczny na proponowane przez środki masowego przekazu treści dotyczące przeszłości, odbywające się dyskusje rodzinne lub towarzyskie oraz działalność instytucji publicznych czy też oficjalnie realizowana polityka historyczna. W kontekście aktywności państwa na polu promocji tradycji historycznej A. Wysocki przedstawił także własną ocenę postaw współczesnych głównych opcji politycznych w odniesieniu do polityki historycznej. Towarzyszyła temu dość zaskakująca klasyfikacja obecnych w polskiej polityce ugrupowań. Wprawdzie autor dokonał ich podziału, skupiając się w głównej mierze na opozycji prawica-lewica, ale nie wyjaśnił niestety, co pod tymi pojęciami rozumie. Doprowadziło to na przykład do kontrowersyjnego umieszczenia Platformy Obywatelskiej oraz Prawa i Sprawiedliwości wśród ugrupowań prawicowych. Wydaje się, że zaproponowana typologia bardziej odwoływała się do medialnych identyfikacji niż naukowej analizy politologicznej ${ }^{27}$. Dyskusyjne jest również przyjęte założenie, że uzasadnienia postawionej tezy o wzmaganiu się w społeczności polskiej ciekawości historycznej i tym samym o rozszerzaniu się zakresu jej pamięci zbiorowej można bez większych problemów poszukiwać w badaniach sondażowych (CBOS i TNS oraz ich poprzedników), wykonywanych począwszy od lat dziewięćdziesiątych XX wieku, aż do 2017 roku. Na pierwsze

stwach katolicyzmem), nie wspomniała o innych Kościołach chrześcijańskich funkcjonujących w wymienionych państwach w kontekście ich ewentualnego udziału w kształtowaniu słownictwa czy światopoglądowej postawy wobec narzuconego reżimu.

26 A. Wysocki, Pamięć zbiorowa o okupacji hitlerowskiej, sowieckiej i o PRL-u jako element współczesnej tożsamości narodowej Polaków w perspektywie badań sondażowych, [w:] Doświadczenie..., s. 453-507.

27 Znana jest geneza tego podziału, sięgającego do czasów rewolucji francuskiej, który zapoczątkował utożsamianie terminu ,prawica” z ,reakcją”, monarchizmem, a pojęcia „lewica” z sympatykami rewolucji, postępu i egalitaryzmu. Współcześnie kategorie „rewolucja” i „reakcja” nie przystają do opisu głównych sił politycznych, czego dobitny przykład może stanowić nierozstrzygnięty spór o przyporządkowywanie poszczególnych systemów totalitarnych (głównie dotyczy to faszyzmu i nazizmu) do prawicowego czy też lewicowego konceptu. Podobnie ma się definiowanie programów politycznych o proweniencji socjalistycznej (socjalnej) i liberalnej, które wykazuje skłonność do zbyt uproszczonej redukcji i generalizacji często bogatej ideowo opcji politycznej (na przykład w USA obecne europejskie rozumienie neoliberalizmu może uchodzić za lewicowy światopogląd, podczas gdy środowiska wyrosłe na gruncie tak zwanej Nowej Prawicy odwołują się do koncepcji klasycznego liberalizmu czy neokonserwatyzmu i nie są wolne od napięć w łączeniu cech radykalizmu, reakcjonizmu czy tradycjonalizmu). Por. A. Heywood, Ideologie polityczne. Wprowadzenie, Warszawa 2007, s. 30-33, 105-114. 
wejrzenie można uznać to stanowisko za w pełni uzasadnione, niemniej jednak, jeżeli uświadomimy sobie nie tylko odmienność sposobu prowadzenia badań przez poszczególne ośrodki sondażowe (łącznie ze sposobem formułowania pytań), lecz także zmienność samych metod pomiaru w poszczególnych ośrodkach związanych z rozwojem techniki (zastępowanie komunikacji bezpośredniej komunikacją środkami technicznymi: telefony stacjonarne i komórkowe, Internet), to wyraźnie ujawni się nam wielość problemów związanych z próbą zestawiania wyników poszczególnych badań. Zresztą sam autor zwrócił uwagę na subiektywny charakter deklaracji będących podstawą części analizowanych badań, który jego zdaniem negatywnie wpływa na wiarygodność wyników, a tym samym na treść końcowych wniosków. Na marginesie należy w tym miejscu zwrócić uwagę na rozbieżności występujące pomiędzy niektórymi komentarzami autora a danymi zawartymi w załączonych tabelach. Przykładem może tu być tekst znajdujący się na stronie 468 komentujący tabele 4 i 5, z którego wynika, że w 2009 roku w opinii $5 \%$ badanych Niemcy wykazali się największym bohaterstwem w czasie wojny (w tabeli 4 poziom wskazań wynosi 0\%) oraz że w 2015 roku w opinii $45 \%$ badanych przypisało Niemcom dużą i bardzo dużą skalę cierpień i ofiar w trakcie II wojny światowej, podczas gdy w tabeli 5 (której ten komentarz dotyczy) takich danych nie zamieszczono. Odrębnym problemem są konstrukcje samych ankiet, w których pojawiają się sformułowania dyskwalifikujące możliwość uzyskania prawidłowych wyników, które jednocześnie nie spotykają się ze szczególną uwagą autora. Dla przykładu można tu wskazać ponownie tabelę 4, w której przyjęto, że pojęcie „Rosjanie” można utożsamić z „,narodem radzieckim" i z ZSRR, Niemców zaś oznaczyć dodatkowo jako hitlerowcy i faszyści. Wydaje się, że uleganie skłonności do posługiwania się dość nieprecyzyjnymi pojęciami czy zwrotami oraz nieuprawnionymi potocznymi skrótami myślowymi niestety może rzutować na analizę ankiet i na wiarygodność niektórych konkluzji w zakresie pamięci zbiorowej i tożsamości narodowej Polaków.

Podsumowując, należy stwierdzić, że praca zbiorowa Doświadczenie dwóch totalitaryzmów. Interpretacje jest kolejną, potrzebną, próbą zmierzenia się przez polskich badaczy z teorią totalitaryzmu oraz z jego zbrodniczymi realizacjami, które boleśnie dotknęły mieszkańców ziem polskich. To tragiczne polskie doświadczenie skutków działania reżimów nazistowskiego i komunistycznego może być przecież uznane za wystarczającą przyczynę podjęcia tej pracy naukowej nad totalitaryzmem. Omówioną publikację, mimo pewnych zastrzeżeń dotyczących doboru literatury, przyjętej metodologii, stawianych tez czy też wyboru szczegółowego przedmiotu badawczego, cechuje spory potencjał twórczy, zwłaszcza ze względu na pomysł ujęcia problematyki w sposób interdyscyplinarny. Warto ponadto podkreślić, że stosunkowo niedługa historia działalności badawczej Ośrodka im. W. Pileckiego może thumaczyć niedostatek doświadczenia (niektórych autorów) w tworzeniu w pełni wartościowych naukowo publikacji. Tym bardziej z poznawczą ciekawością należy oczekiwać zapowiadanego przez redaktorów tomu następnego 
projektu badawczego poświęconego ciągle niewyczerpanemu tematowi z zakresu polskich doświadczeń totalitaryzmów, a w głównej mierze ważkich aspektów funkcjonowania i oddziaływania władzy komunistycznej w dobie PRL-u.

\section{Bibliografia}

Arendt H., Korzenie totalitaryzmu, t. 1-2, Warszawa 1993.

Bankowicz M., Totalitaryzm, [hasło w:] Słownik społeczny, red. B. Szlachta, Kraków 2004.

Doktryny polityczne XIX i XX wieku, red. K. Chojnicka, W. Kozub-Ciembroniewicz, Kraków 2000.

Doświadczenie dwóch totalitaryzmów. Interpretacje, red. P. Kaczorowski, M. Kornat, J. Lubecka, P. Madajczyk, Warszawa 2018.

Heywood A., Ideologie polityczne. Wprowadzenie, Warszawa 2007.

Jonca K., Dekrety prezydenta Edvarda Beneša. Niemcy w czechostowackiej doktrynie politycznej i prawnej z lat 1920-1945, Wrocław 2005.

Jonca K., Noc kryształowa i casus Herschela Grynszpana, Wrocław 1992.

Jonca K., Polityka narodowościowa Trzeciej Rzeszy na Śląsku Opolskim 1933-40. Studium polityczno-prawne, Katowice 1970.

Jonca K., Konieczny A., Nuit et Brouillard. L'operations terroriste nazie 1941-1944, Claviers 1981.

Konieczny A., Akcja „Noc i mgła” w okupowanych przez III Rzeszę krajach zachodniej Europy. Geneza, założenia, realizacja, Wrocław 1995.

Konieczny A., Pod rządami wojennego prawa karnego Trzeciej Rzeszy, Górny Ślask 1939-1945, Katowice 1972.

Konieczny A., Tormersdorf-Grüssau-Riebing. Obozy przejściowe dla Żydów Dolnego Śląska z lat 1941-1943, Wrocław 1997.

Kruszewski T., Partia narodowosocjalistyczna na Śląsku w latach 1933-1945. Organizacja i dziatalność, Wrocław 1995.

Machaj Ł., Scheffler T., Z badań nad procesem totalitaryzacji w nazistowskich Niemczech, „Studia nad Faszyzmem i Zbrodniami Hitlerowskimi” 27, 2004.

Maciejewski M., Doktryna rewolucyjnego konserwatyzmu wobec narodowego socjalizmu 19211945, Wrocław 1991.

Maciejewski M., Od piwiarnianego klubu do organizacji wywrotowej. Nazizm 1921-1924, Toruń 2005.

Maciejewski M., Ruch i ideologia narodowych socjalistów w Republice Weimarskiej. O źródłach i początkach nazizmu 1919-1924, Warszawa-Wrocław 1985.

Marszał M., Włoski faszyzm i niemiecki narodowy socjalizm w pogladach ideologów narodowej demokracji 1926-1939, Wrocław 2001.

Marszał M., Włoski faszyzm w polskiej myśli politycznej i prawnej 1922-1939, Wrocław 2007.

Olszewski H., Zmierczak M., Historia doktryn politycznych i prawnych, Poznań 1993.

Paxton R.O., Anatomia faszyzmu, Poznań 2005.

Polskie interpretacje totalitaryzmu i autorytaryzmu, red. M. Maciejewski, M. Marszał, „Studia nad Faszyzmem i Zbrodniami Hitlerowskimi” 33, Wrocław 2011.

Połomski F., Aspekty rasowe w postępowanie z robotnikami przymusowymi i jeńcami wojennymi w III Rzeszy (1939-1945), Wrocław 1976.

Połomski F., Niemiecki urząd do spraw mniejszości, Wrocław 1965.

Połomski F., Prawo własności a tzw. rozwiazanie kwestii żydowskiej w Niemczech hitlerowskich, Wrocław 1991. 
Połomski F., Ustawodawstwo rasistowskie III Rzeszy i jego stosowanie na Górnym Śląsku, Wrocław 1970.

Rezik A., Hersch Lauterpacht (1897-1960) - droga do nauki prawa międzynarodowego, „Palestra" 2017, nr 10.

Rzegocki A., Totalitaryzm, [hasło w:] Stownik historii doktryn politycznych z suplementem, t. 6, red. K. Chojnicka, M. Jaskólski, Warszawa 2015.

Scheffler T., Europa po Hitlerze. Lad międzynarodowy w koncepcjach konserwatywnej opozycji w Trzeciej Rzeszy, Wrocław 2006.

Scheffler T., Prawne aspekty wprowadzenia stanu wojennego w Polsce $w$ dniu 13 grudnia 1981 r., [w:] Idee jako źródto instytucji politycznych i prawnych, red. L. Dubel, Lublin 2003.

Scheffler T., Przestępstwo publicznego propagowania faszystowskiego lub innego totalitarnego ustroju państwa (art. 256 k.k.). Analiza doktrynologiczna wybranych wypowiedzi piśmiennictwa i judykatury. Część ogólna, „Studia nad Autorytaryzmem i Totalitaryzmem” 34, 2012, nr 3.

„Studia nad Faszyzmem i Zbrodniami Hitlerowskimi” 25, 2002.

Totalitaryzm a zachodnia tradycja, red. M. Kuniński, Kraków 2006.

Totalitaryzmy XX wieku. Idee, instytucje, interpretacje, red. W. Kozub-Ciembroniewicz, H. Kowalska-Stus, B. Szlachta, M. Kiwior-Filo, Kraków 2010.

Upadek „Festung Breslau”, oprac. K. Jonca, A. Konieczny, Wrocław 1963.

Wysiedlenia Niemców i osadnictwo ludności polskiej na obszarze Krzyżowa-Świdnica (Kreisau-Schweidnitz) w latach 1945-1948 / Die Aussiedlung der Deutschen und die Ansiedlung der polnischen Bevölkerung im Raum Krzyżowa-Świdnica (Kreisau-Schweidnitz) 1945-1948. Dokumentenauswahl mit Einleitung, red. K. Jonca, M. Maciejewski, współpr. M. Marszał, K. Ruchniewicz, M. Sadowski, T. Scheffler, Wrocław 1997.

\section{POLISH INTERPRETATIONS OF TOTALITARIANISM: ON SOME OF THE RESULTS OF THE WORKS CARRIED OUT AT THE WITOLD PILECKI CENTRE FOR RESEARCH ON TOTALITARIANISM}

\section{Summary}

The theory and practice of totalitarianism, despite the passage of time since the collapse of the systems showing its features in Europe, still arouses intellectual curiosity. This subject matter is also particularly interesting from the Polish point of view, as the native reflection on the subject (reaching back in the tradition of political and legal thought to the interwar period) shows the richness of often innovative research findings made by several generations of scientists in Poland and abroad. The subject of their exploration concerns not only the constitutive assumptions of totalitarianism and its fascist, Nazi and communist systemic forms, but also the peculiar domestic experiences that accompanied the inhabitants of Polish lands during World War II and the Cold War. This unique historical situation, in which the Republic of Poland had been entangled, creatively provokes to discover, archive and popularize knowledge in this field. Thus, it obliges to perpetuate materially and mentally important and tragic Polish experiences. Numerous publications, showing above all the perspective of the Polish interpretation, also make it possible to confront the positions of Polish researchers with the scientific findings from other parts of the world, as well as to take part in the international discourse with full legitimacy. The abovementioned motives were undoubtedly the main reasons for the creation of the collective work Experiencing two totalitarianisms: Interpretations published this year by the Witold Pilecki Centre for Research on Totalitarianism. Apart from other publications on totalitarian systems analysis, which have been published in Poland in recent years, it is an important research contribution to a subject which is completely unknown (mainly as a result of the practices of the People's Republic of Poland), but which is necessary in order to consolidate and settle ac- 
counts with the difficult past. This work can also be considered scientifically attractive because of the interdisciplinary (historical, political, philosophical-political, legal and literary) approach to the subject matter intended by its authors and editors.

Keywords: totalitarianism, nazism, communism, fascism, Poland, Lithuania, Slovakia.

Ewa Kozerska

ekozerska@uni.opole.pl 